\title{
Tools for interpreting Christ's saving mysteries in scripture: Aquinas on reduplicative propositions in christology
}

\author{
J. David Moser \\ Perkins School of Theology, Southern Methodist University, Dallas, TX, USA \\ ${ }^{*}$ Corresponding author. E-mail: dmoser@mail.smu.edu
}

\begin{abstract}
This article examines how Thomas Aquinas used reduplicative propositions (e.g. 'Christ suffers insofar as he is a human being') to explicate Christ's saving mysteries, or events that Christ did and suffered that produced states of affairs only God can do. Following scripture's focus on Christ as one acting subject, Aquinas argued that we should use the adverbial modifiers 'authoritatively as God and instrumentally as a human being' to speak well of Christ's saving mysteries as actions of a single subject. This approach is theologically beneficial because it avoids the pitfalls of thinking of Christ's natures as agents.
\end{abstract}

Keywords: Chalcedon; christology; incarnation; reduplication; theandric; Thomas Aquinas

The Gospel of Matthew narrates a memorable episode in the life of Christ where he does something only God can do, to the onlookers' astonishment and the scribes' dismay. ${ }^{1}$ A group of people carrying a paralysed man on a bed bring him before Jesus, where Jesus tells him, 'Take heart, son; your sins are forgiven' (Matt 9:2). ${ }^{2}$ Undoubtedly with scepticism, the scribes murmur: surely, this man is blaspheming. Who can forgive sins but God alone (cf. Luke 5:21)? Jesus did not hear them, but he 'knew their thoughts', and rebuked them (Matt 9:4). Speaking, 'so that you may know that the Son of Man has authority on earth to forgive sins', he turned to the paralytic and said, '[s]tand up, take your bed, and go home' (Matt 9:6). And this happened as Jesus said it would. The crowd marvelled, for God had given authority to this human being to do something only he can do. How could this be? Should we say that Christ forgave these sins as God, as a human being, or as both?

This question flags a perennial problem in christology: how to speak of Christ's actions that bear saving power. Christians confess that God alone can forgive sins. But scripture tells us that Christ's actions (i.e. his voluntary human actions displayed in the New Testament) bring about states of affairs only God can produce. ${ }^{3}$ Thomas

\footnotetext{
${ }^{1}$ All biblical translations come from the New Revised Standard Version (NRSV) unless otherwise noted.

${ }^{2}$ See the parallel accounts of this episode in Mark 2:1-12 and Luke 15:17-26.

${ }^{3}$ On the voluntary character of human action, see Thomas Aquinas, Summa Theologiae [hereafter ST] 1/ 2.6.1. In this article, I use the following editions of Aquinas' work: Expositio et lectura super epistolas Pauli Apostoli, ed. Raphael Cai (Turin and Rome: Marietti, 1953); Opuscula Theologica, ed. R. A. Verardo, stricted re-use, distribution, and reproduction in any medium, provided the original work is properly cited.
} 
Aquinas and a long spiritual tradition after him called these actions 'the mysteries of Christ's life': events he willed that bear saving power for us, like his birth, teaching, miracles, passion, death, resurrection and ascension. ${ }^{4}$ For centuries, Christians have marvelled at these with his disciples, asking, 'what sort of man is this, that even the winds and the seas obey him' (Matt 8:27)?

The conciliar tradition went to great lengths to provide answers to this question. Central to these efforts is Pope Leo the Great's Tome to Flavian, which the Council of Chalcedon accepted; it offered influential, doctrinally normative teaching on Christ's two natures, refined into a memorable dictum: 'For each nature does what is proper to it in communion with the other: the Word does what pertains to the Word, and the flesh to what pertains to the flesh. One shines forth with miracles; the other succumbs to injuries. ${ }^{5}$ Over two centuries later, the third Council of Constantinople (681) took Leo to be teaching about Christ's two natural wills and energies. ' 'Energy', translated into the Latin form operatio, refers to the type of action that goes with a nature. The council leaves open how Christ's human energy and his human actions in scripture cause our salvation and other things God alone can do. It only claims that Christ's two natural wills and energies 'concur together for the salvation of the human race.' ${ }^{7}$ Recall that according to Chalcedonian christology, 'persons' are subjects of properties; 'natures' categorise properties into groups. If a person has a certain group of properties, that person belongs to that nature. Christ is one person in two natures: one person with two sets of properties that place him in two different groups, divinity and humanity, and these groups have distinct types of action that belong to them. Thus, the conciliar tradition explains how Jesus forgives sins by attending to the distinct types of action proper to his natures, or his two energies.

However, Christ's saving mysteries reveal a problem with using the distinction of natures as hermeneutical guides to interpret them. For this distinction can mislead by creating the thought that Christ's two natures are subjects of action. ${ }^{8}$ So, on one reading, when Christ walks to Jerusalem, he does this humanly, but when he forgives sins, he does this divinely and humanly, so that humanity switches on and divinity switches off in the former, and both switch on for the latter. The ultimate source of Christ's actions told in scripture, on this view, would be his natures. Yet scripture insists that Christ is a single subject. In no way am I suggesting that the conciliar tradition is

R. M. Spiazzi and M. Calcattera, 2 vols (Turin and Rome: Marietti, 1954), which contains the disputed question De unione verbi incarnati; Scriptum super Libros Sententiarum [hereafter Sent.], ed. P. Mandonnet and M. F. Moos, 4 vols (Paris: Lethielleux, 1929-47); Summa Theologiae, ed. Petrus Caramello, 3 vols (Turin and Rome: Marietti, 1952-6); Super Evangelium S. Ioannis Lectura [hereafter In Ioan.], ed. Raphael Cai (Turin and Rome: Marietti, 1952). All translations from the Latin are my own unless otherwise noted.

${ }^{4}$ Aquinas, $S T$ 3.62.5.1, 3.66.3. Aquinas calls the saving mysteries of Christ's life the 'actions and sufferings' (acta et passa) of Christ in the flesh (ST 3, prol., cf. In Rom. 8, lect. 7, no. 720, In Eph. 3, lect. 5, no. 178). In ST 3.27-59 he treats the life of Christ and the various mysteries.

${ }^{5}$ Leo I, 'Tomus Leonis', in Heinrich Denzinger, Enchiridion symbolorum definitionum et declarationum de rebus fidei et morum [hereafter DH], 43rd edn, ed. Peter Hünermann (San Francisco: Ignatius, 2012), $\$ 294$, translation slightly altered. The Council of Chalcedon formally approved Cyril's letters to Nestorius and Leo's Tome (DH §300).

${ }^{6}$ Third Council of Constantinople, 'Definition on the Two Wills and Operations of Christ', DH $\$ 557$.

${ }^{7}$ Ibid., DH $\$ 558$ (translation altered).

${ }^{8}$ One can find a recent variation of this critique in Rowan Williams, Christ the Heart of Creation (London: Bloomsbury Continuum, 2018), pp. 86-8. 
wrong or in error but taking them as a rule for reading scripture can be misleading if it detracts focus from Christ being a single person who acts. Leo's Tome and the conciliar tradition to which it belongs are necessary ontological explanations of what scripture teaches. But in the case of Christ's mysteries, we need more precise language to focus our minds on the person of Christ as the subject of these actions: ones that bear divine and human effects, like Jesus forgiving sins by speaking humanly, as he did for the paralytic.

Thomas Aquinas and his medieval contemporaries developed modes of analysis conducive to a solution. Aquinas used reduplicative propositions, or propositions that include a qualifier like 'as' or 'insofar as', as in the proposition ' $\mathrm{X}$ is $\mathrm{P}$ qua F', to test the limits of what can be said of Christ's person and actions. Through testing these propositions, we can better understand what we should and should not say about Christ's saving mysteries. This article argues that theologians should follow Aquinas' use of reduplicative adverbial modifiers to speak of Christ's saving mysteries. While ontological explanations can create the thought that natures are acting subjects, Aquinas's solution better aligns our thoughts on Christ as the sole subject of these actions.

\section{Scriptural speech and ontological explanations}

Scripture is resolutely focused on the thought that Christ is one person. As Aquinas observes, it regularly 'attributes the things of God to that man, and the things of that man to God indistinctly'. 'Examples include John 1:14 ('And the Word became flesh and lived among us') and also 1 Corinthians 2:8 ('they would not have crucified the Lord of glory'), among others (cf. Acts 20:28). Scripture without fail identifies the eternal Word and the man Jesus Christ as the same person and the sole subject of his human actions, including his mysteries. Thus, how we speak of Christ's mysteries and his two natures should be disciplined by this reality. To this end, Aquinas appeals to the Aristotelian axiom 'acts belong to supposits' (actus sunt suppositorum): actions belong to subjects, not their natures. ${ }^{10}$ The Logos is the subject of all his actions and sufferings as a human being. And this axiom does not contradict speech about Christ's two energies, the types of action that correspond to his two natures. For the actions a person can do depend on the nature she has. ${ }^{11}$ These logically basic thoughts must discipline how we speak of Christ and his mysteries.

While biblical statements focus on Christ's singularity, the ontological explanations offered in the conciliar tradition give an account of the state of affairs that must be true if what scripture says about Christ is true. ${ }^{12}$ For Aquinas, the central explanation of Christ's person is 'hypostatic union', the notion that Christ has a divine nature and a human nature that are united 'according to one hypostasis and suppositum', and this

\footnotetext{
${ }^{9}$ Aquinas, $\operatorname{ScG}$ 4.39.1. My interpretation of Aquinas here is heavily indebted to the analysis of Bruce D. Marshall, Christology in Conflict: The Identity of a Saviour in Rahner and Barth (Oxford: Basil Blackwell, 1987), pp. 176-89. Readers would do well to examine his analysis there and the book as a whole for a fuller understanding of these issues.

${ }^{10}$ See e.g. Aquinas, ST 1.39.5.1.

${ }^{11}$ Aquinas, ST 3.19.1.3.

${ }^{12}$ How I understand the ontology-laden character of conciliar language concurs with Sarah Coakley, 'What does Chalcedon Solve and What does it Not?', in Stephen T. Davis et al. (eds), The Incarnation: An Interdisciplinary Symposium on the Incarnation of the Son of God (Oxford: Oxford University Press, 2002), pp. 143-63.
} 
explanation works because it can 'save' (salvari) scripture's meaning. ${ }^{13}$ In fact, Aquinas thinks hypostatic union is 'the only way that which scripture hands down about the incarnation can be saved'. ${ }^{14}$ Now he is not saying that scripture needs to be 'saved' from incoherence. Rather, given that scripture attributes things of the man Jesus to the Word and vice versa, theology must give a proper ontological account of Christ that renders this way of speaking more intelligible.

If theology's aim is to save the biblical way of speaking about Christ, it must revise ontological statements if they fail to provide the right sense to that way of speaking. For example, according to Aquinas, Nestorians and Catholic Christians agree that Paul's sentence calling Christ 'the Lord of glory' is true (1 Cor 2:8), but they disagree in the sense in which that claim is true. Aquinas characterises Nestorian belief as the notion that there are 'two hypostases or supposita in Christ'. ${ }^{15}$ And for him, this belief does not fit with scripture's language about Christ. For the Gospel of John teaches that the Word, a divine person, became flesh (John 1:14). Nestorius did not understand the Evangelist's statement about Christ, Aquinas argues, because he thought the Son of God was united to a man so that more than one person resulted. ${ }^{16}$ Yet scripture plainly says that one person, the Word, became flesh, so that only one person results. So if Nestorius thinks there were two persons in Christ, then he undercuts the language of scripture: if he is right, 'then what the Evangelist says is not true'. ${ }^{17}$ Although Aquinas does not say this explicitly, the language of hypostatic union, two wills and two energies in Christ is the only way to explain what scripture says about Christ, for it specifies that he is one person and that divinity and humanity are present and distinct in him. For as Augustine trenchantly noted, scripture insists that this one person exists in two 'forms' - the form of God and the form of a servant, and the letter to the Philippians warrants this directly (Phil 2:6-11). ${ }^{18}$

Beyond the conciliar tradition, John Damascene and Pseudo-Dionysius before him offered influential explanations of how Christ's human actions save. In his On the Orthodox Faith, the third part of his Fount of Knowledge, John Damascene paired Leo's dictum with Pseudo-Dionysius' famous yet controversial 'new theandric energy' to explain what must be the case in Christ for his human actions to be saving. ${ }^{19}$ For John, Christ saves us by means of his instrumental humanity, which is truly his instrument because his human energy exists in a 'connection' (Greek synaphēs) with his divine energy. ${ }^{20}$ Like many patristic writers before him, he invoked the iron and fire analogy to explain this connection. Just as an iron blade glows red as it contacts fire,

\footnotetext{
${ }^{13}$ Aquinas, $S c G$ 4.39.1. On the incarnation taking place in a union according to hypostasis, see ST 3.2.3, and De unione, a. 1.

${ }^{14}$ Aquinas, $S c G$ 4.39.1.

${ }^{15}$ Aquinas, ST 3.2.6.

${ }^{16}$ Aquinas, In Ioan. 1, lect. 7, no. 174.

${ }^{17}$ Aquinas, In Ioan. 1, lect. 7, no. 170.

${ }^{18}$ Augustine, On the Trinity 1.13.28-9, in The Trinity, 2nd edn, trans. Edmund Hill (Hyde Park, NY: New City Press, 2012), pp. 91-6. Cf. Corpus Christianorum Series Latina, vol. 40 (Turnhout: Brepols, 1968), 69-73.

${ }^{19}$ For the reference in Pseudo-Dionysius, see his 'Letter 4 to Gaius' in Pseudo-Dionysius: The Complete Works, trans. Colm Luibheid (New York: Paulist Press, 1987), pp. 264-5. Cf. Corpus Dionysiacum, vol. 2, ed. Adolf Martin Ritter and Gunter Heil (Berlin: Walter de Gruyter, 2012), pp. 160-1.

${ }^{20}$ John Damascene, On the Orthodox Faith 3.15 in St. John of Damascus: Writings, trans. Frederic H. Chase, Jr (Washington, DC: Catholic University of America Press, 1958), p. 306. Cf. John Damascene, Die Schriften des Johannes von Damaskos, vol. 2, ed. Bonafatius Kotter (Berlin: Walter de Gruyter, 1969), p. 146, 1. 48.
} 
so too does Christ's humanity get the power to drive out sin and death by divine power. ${ }^{21}$ But in this connection, neither iron nor fire become the same thing, eliding their natural distinction. So it is with Christ's two natures and energies. And Christ's two energies concur to a single 'theandric action' narrated in scripture, which is a complex state of affairs comprised of a human end-product and a divine end-product. ${ }^{22}$ To take one example: when Jesus heals the deceased child, he takes her by the hand humanly and restores her to life divinely, so that she is raised from the dead (Luke 8:54-5). The two end-products of his two energies are the touching and the healing, and these concur to one state of affairs, the resurrection of this girl.

These explanations - conciliar and not - focus on Christ's two natures and energies as sources of action. And they inform how we think of Christ's mysteries narrated in scripture in that, in these events, both of his energies are implicated. To read scripture this way does not create two acting subjects. John Damascene reminds us that sometimes we have to speak of the two natures in Christ, and other times of his person. We can do this, after all, because 'the two natures are one Christ and the one Christ is two natures' ${ }^{23}$ In both cases, we speak of the natures insofar as the Logos, a single person, possesses them. To say, then, that Christ acts according to his human nature alone in walking to Jerusalem and according to both natures in raising the girl from the dead refers to acts of the same person. But questions remain. Scripture teaches that Christ suffers 'according to the flesh' (1 Pet 4:1). But since his fleshly suffering brings about our salvation (cf. Rom 3:21-6), and so it counts as one of Christ's mysteries, does he act in that suffering according to both natures? We might jump to the deliverances of recent literature defending divine impassibility and think 'no'. ${ }^{24}$ Christ's divine energy is exempt from his human suffering. Does it follow that Christ's death does not save us? Does each form in Christ really do what is proper to it in communion with the other in a connection, as the Damascene explained? Following Leonine grammar, we could suppose that one nature of Christ 'acts' in the suffering on the cross and the other 'acts' by destroying sin and death in that suffering. Yet according to Chalcedon and Cyril, Christ in scripture is one person and speaker. ${ }^{25}$ This solution does not attract the mind to a single acting subject but focuses on Christ's two energies or sources of action. To take these explanations as a rule for reading scripture can be misleading if it detracts focus from Christ being a single person who acts.

\footnotetext{
${ }^{21}$ John Damascene, On the Orthodox Faith 3.15 (Chase, pp. 308-9; Kotter, p. 148, 11. 104-19). This analogy goes back to Origen, On First Principles 2.6.6 in Origen, On First Principles, trans. G. W. Butterworth, rev. John C. Cavadini (Notre Dame, IN: Ave Maria Press, 2013), pp. 141-2. Cf. Origen, Traité des principles, Tome I (Livres I et II), trans. H. Crouzel and M. Simonetti (Paris: Les Éditions du Cerf, 1978), p. 321. On the history of this idea, see Dmitry Biriukov, 'Penetration of Fire into Iron: The Sense and Usage Mode of This Metaphor for Description of Theosis in the Byzantine Theological Literature', Scrinium 15 (2019), pp. 146-7.

${ }^{22}$ John Damascene, On the Orthodox Faith 3.19 (Chase, p. 323; Kotter, pp. 161-2, 11. 40-51).

${ }^{23}$ Ibid. (Chase, p. 322; Kotter, p. 161, 1l. 22-3).

${ }^{24}$ On divine impassibility in the patristic period, see Paul L. Gavrilyuk, The Suffering of the Impassible God: The Dialectics of Patristic Thought (Oxford: OUP, 2006). For an insightful account that addresses modern criticisms of divine impassibility by addressing the distinction between person and nature, see Bruce D. Marshall, 'The Dereliction of Christ and the Impassibility of God', in James F. Keating and Thomas Joseph White (eds), Divine Impassibility and the Mystery of Human Suffering (Grand Rapids, MI: William B. Eerdmans, 2009), pp. 246-98.

${ }^{25}$ Cyril of Alexandria, 'Third Letter to Nestorius', $\$ 8$ in Cyril of Alexandria: Select Letters, ed. and trans. Lionel R. Wickham (Oxford: Clarendon, 1983), pp. 22-5; and anathema 4, pp. 30-1.
} 
We need a better way to speak of Christ's saving mysteries that focuses on Christ as the sole subject of these actions.

Adjudicating these matters is difficult because, as Aquinas observes, the realities to which scripture and these ontological explanations refer are divine, and human beings do not have the capacity to describe or explain these realities exhaustively. In his disputed question On the Union of the Incarnate Word, written near the end of his life, Aquinas explains why various christological heresies fail and defends the concept of 'hypostatic union'. This union, he says, can best be compared to the union of soul and body: 'among created things no example of this union is closer than [this one]'. ${ }^{26} \mathrm{He}$ ends his analysis on an epistemically sombre note.

But all of these examples are deficient ... this is a certain singular union above all other modes of union known to us. For just as God is goodness itself and being itself, so also is he unity itself by essence. And therefore, just as his power is not limited to those modes of goodness and being which are in creatures, but he can make new modes of goodness and being unknown to us, so also by his infinite power he can make a new mode of union, so that human nature would be united to the Word personally, and not accidentally, although no example of this could be discovered among creatures. ${ }^{27}$

Aquinas had a strong sense that the hypostatic union could not be fully explicated because it transcends human knowledge, both natural and graced. He was likely following Cyril, who argued that the union 'according to hypostasis' (kath' hypostasin) was accomplished 'inexpressibly' (aphrastōs) and 'inconceivably' (aperinoētōs). ${ }^{28}$ Now God has revealed the incarnation in scripture, and the ancient church acting in council taught that the mode of union in Christ is 'hypostatic union'. ${ }^{29}$ Thus, we can describe it with these concepts, but we should not be surprised when ontological explanations of Christ's two natures fail to describe their object satisfactorily. As nearly every student of christology is aware, christological explanations can become increasingly complicated. Not only do post-Reformation treatises on the ubiquity of Christ's humanity come to mind, but this is also true of the controversy over Leo's Tome. ${ }^{30}$ These explanations are necessary to guide scriptural reading and Christian worship, especially the Tome, since Catholics, Orthodox and most major Protestant communions accept it as an authoritative document. But if we rely on them to explain scripture, we can lose scripture's central insight: that Christ is one person who accomplishes his mysteries as a human being. These explanations are necessary to save scripture's sense, but they do not solve every problem.

\footnotetext{
${ }^{26}$ Aquinas, De unione, a. 1, c.

${ }^{27}$ Ibid.

${ }^{28}$ Cyril of Alexandria, 'Second Letter to Nestorius', $\$ 3$, in Cyril of Alexandria: Select Letters, pp. 4-7.

${ }^{29} \mathrm{On}$ scripture as incontrovertible proof of what is contained in sacred doctrine, see Aquinas, ST 1.1.8.2. On the articles of faith, like the incarnation, which lead us to the first truth, ST 2/2.1.6-8.

${ }^{30}$ The exemplary text is Martin Chemnitz, De duabus naturibus in Christo, 2nd edn (Leipzig, 1580); ET: On the Two Natures in Christ, trans. J. A. O. Preus (St Louis, MO: Concordia, 1971). For an incisive account of Reformation developments on the communion of natures (communicatio naturarum) in Christ, see Richard Cross, Communicatio Idiomatum: Reformation Christological Debates (Oxford: OUP, 2019).
} 


\section{Reduplicative propositions in christology}

To discipline our speech about Christ's mysteries, we should attend first to a critical distinction between concrete and abstract terms, used in both trinitarian theology and christology in the ancient and medieval periods. In christology concrete terms refer to the person; and given conciliar standards, they refer to one person. Thus 'Word', 'Logos' and 'Jesus Christ' refer to the same person. Scripture always uses concrete terms as the subject of sentences where Christ acts. Consider an example. The Gospel of Luke says, 'When the day drew near for him to be taken up, he set his face to go to Jerusalem' (Luke 9:51). 'He' here refers to Jesus Christ, whom Chalcedon confesses to be one and the same with the eternally begotten Son of God, the one who took on flesh and dwelt among us (cf. John 1:14). ${ }^{31}$ That person, goes to Jerusalem. By contrast, abstract terms refer to Christ's two natures. These are terms like 'humanity' and 'divinity'. Recall that natures are groups of properties that a subject must have to be a member of a class. Thus, natures are not persons, and so not acting subjects. Scripture teaches Christ 'suffered in the flesh' (1 Pet 4:1), that is, he (not his human nature) suffered because he has a nature that makes it possible for him to suffer. But he, the divine Word, is the one who suffers. So we cannot place abstract terms in the subject line of a proposition; we should not say 'the humanity of Christ set his face to go to Jerusalem', since natures do not act, but persons do.

This distinction is important to keep straight, for according to Aquinas, concrete and abstract terms do not have the same 'way of signifying' (modus significandi). For example, the concrete term 'Son of God' signifies the eternal Word who became incarnate; 'Son of God' signifies in the mode of a person who acts. By contrast, 'divine nature' or 'essence' does not signify in the mode of a person, but in the way of an essence. Thus it does not signify an acting subject. We do not say, 'the divine nature became incarnate', but 'the Son became incarnate. ${ }^{32}$ Furthermore, things said of one nature cannot be said of the other. Thus Christ's natures, divinity and humanity, are not the same: ' $\mathrm{t}$ ] hings which are of one thing properly cannot be truly predicated of another unless they are the same'. ${ }^{33}$ In the incarnation, divinity and humanity are not the same, and thus properties belonging to one cannot be predicated of the other. However, concrete terms - which stand for the person - can be predicated of one another, since they refer to the same person. And finally, abstract terms - which stand for natures - can be predicated of various concrete terms, since one person possesses two natures. Thus, divine predicates can be applied to the man Jesus Christ, in sentences like 'this man created the stars', and human predicates can be applied to the eternal Word, in sentences like 'the Word suffered on the cross', since the same person is the subject of both sentences. ${ }^{34}$

With these terminological distinctions in mind, Aquinas investigates Christ's 'being and becoming' (esse et fieri) in Summa Theologiae 3.16 by testing the truth of the sentences 'God is man' and 'man is God'. ${ }^{35}$ He likely begins with these two because of scripture's focus on the fact that the Word and the man Jesus are the same person. In these test-case sentences, 'God' and 'man' are predicated of one another in the concrete, not abstractly: 'divinity' and 'humanity'. As his analysis reveals, in Christ, the one who is God is the same as the one who is man, so the sentences must be true. Later he considers

\footnotetext{
${ }^{31}$ Council of Chalcedon, 'Definition of Faith', DH $\$ 302$.

${ }^{32}$ Aquinas, ST 3.16.5.1; cf. 1.39.5.

${ }^{33}$ Aquinas, ST 3.16.5.

${ }^{34}$ Aquinas, ST 3.16.4. This is what traditionally known as the communicatio idiomatum.

${ }^{35}$ Aquinas, ST 3.16.1-2.
} 
other predications, like 'Christ is a creature'. ${ }^{36}$ In this case, the sentence as it stands must be false, amounting to Arianism. But we can affirm the sentence is true if we add a qualifier: 'according to his human nature' (secundum humanam naturam). The predication would then be 'Christ according to his human nature is a creature'. The predication works similarly to the way parts are predicated of a whole: parts of a whole are not predicated of the whole without qualification. Rather, parts are predicated of a whole by specifying the respect in which the part belongs to the whole. Aquinas' well-known example is that we do not say 'an Ethiopian is white', but 'an Ethiopian is white according to his teeth'. This type of qualification of a proposition is known as reduplication.

Reduplicative propositions specify the reason why the predicate applies to the subject by using the qualifier 'as' or 'insofar as' (in Latin, secundum quod and its variants). For a particular branch of medieval semantic analysis, or 'modistic' logic, the goal of analysing the logical properties of propositions is to analyse the relation of the terms in those propositions. Logicians seek the semantic properties of terms in a proposition, which specify the relation of the terms. Two modes of this kind of analysis gradually emerged in the twelfth century and developed further in the thirteenth. The first was the theory of signification, which explains 'the capacity of descriptive terms to function as signs', and the second is the theory of supposition, which interrogates the different modes of the use of terms as subject and predicate. ${ }^{37}$ Analysis of reduplicative propositions tended to fall in the purview of the theory of supposition: it analyses how the relationship between the terms changes with the modifier added.

Reduplicative propositions include the semantic property of 'the qua-connective', manifested by qualifiers like 'as' or 'insofar as'. These qualifiers specify the sense in which the predicate applies to the subject. ${ }^{38}$ Aquinas offers a formal definition of reduplicative propositions in his Commentary on the Sentences: 'That which is reduplicated in some proposition when I say "insofar as" is that on account of which the predicate belongs to the subject. ${ }^{39}$ A reduplication, then, signifies the respect in which the predicate is applied to the subject. A reduplicative proposition can be stated formally as ' $\mathrm{X}$ is $\mathrm{P}$ qua F', where qua is the reduplicative modifier. For example, in the proposition 'a tree is brown', the reduplication 'insofar as it has a trunk' can be added to specify that on account of which 'brown' applies to 'tree'. In the case of Christ, 'the Lord of glory was crucified' is true, but the reason 'crucified' applies to the subject (the Lord) is his human nature. Thus, the apt reduplicative qualifier to apply to Christ in this proposition is 'insofar as he is a human being' (in Aquinas' way of putting it, secundum quod homo), so that we get 'the Lord of glory was crucified insofar as he is a human being. ${ }^{40}$ And this way of speaking matches scripture's way of speaking: he, a divine person, was crucified, but only in virtue of the flesh he assumed. As already mentioned, Peter prepares his listeners to suffer by reminding them that Christ 'suffered in the flesh'

\footnotetext{
${ }^{36}$ Aquinas, ST 3.16.8.

${ }^{37}$ Christoph Kann, 'Supposition and Properties of Terms', in Catarina Dutilh Novaes and Stephen Read (eds), The Cambridge Companion to Medieval Logic (Cambridge: CUP, 2016), p. 221. For the broader historical background in medieval modistic grammar, see Jan Pinborg, 'Speculative Grammar', in Norman Kretzmann et al. (eds), The Cambridge History of Later Medieval Philosophy: From the Rediscovery of Aristotle to the Disintegration of Scholasticism 1100-1600 (Cambridge: CUP, 1982), pp. 254-69.

${ }^{38}$ Allan Bäck, On Reduplication: Logical Theories of Qualification (Leiden: Brill, 1996), p. xv.

${ }^{39}$ Aquinas, III Sent., d. 10, q. 1, a. 1, r.

${ }^{40}$ Thus Christ's passion is to be attributed to him not insofar as he is God, but insofar as he is a human being (Aquinas, ST 3.46.12). See similar predications applied to Christ's subjection to the Father (3.20.1.1), his priesthood (3.22.3.1) and his predestination (3.24.2 $\mathrm{c}$ and ad 1), among others.
} 
(pathontos sarki; 1 Pet 4:1). Likewise, for Paul, Christ is a descendant of David 'according to the flesh' (kata sarka) and declared the Son of God in power 'according to the Spirit of holiness' (kata pneuma hagiosuness) because of his resurrection from the dead (Rom 1:3-4). Other examples include Romans 9:5, Colossians 1:22 and 1 Peter $3: 18 .^{41}$ Perhaps for this reason, for Aquinas, the predicate term in a reduplicative proposition signifies natures by abstract terms, and not persons. ${ }^{42}$

\section{Speaking of Christ's mysteries}

Near the end of Summa Theologiae 3.16, Aquinas tests the truth of three reduplicative propositions: 'Christ as a human being is a creature' (a. 10), 'Christ as a human being is God' (a. 11) and 'Christ as a human being is a hypostasis or person' (a. 12). For our purposes, I restrict discussion here to his analysis of 'Christ as a human being is God'. First, recall the Gospel episode retold in the introduction. There Christ, as a human being, forgave sins, something only God can do. Does it follow, then, that Christ, as a human being, is God? This is another way of asking whether both natures are involved in this event. According to this test reduplicative proposition, the respect in which 'God' applies to the subject 'Christ' is 'insofar as he is a human being'. Thus, the reason for the truth of the predication 'Christ is God' is that he has a human nature. Is this the right way to speak of Christ's mysteries?

Aquinas concludes that this proposition, understood in this way, is false, for terms in a reduplicative qualifier (in this case, 'as a human being') signify a nature. ${ }^{43}$ If we remove the qualifier, we would get 'Christ is God', which is the same as 'Christ is divine'. Thus, if we add the reduplication 'as a human being' back in, we get 'Christ as a human being is divine'. This would be like saying, 'Christ insofar as he is a human being is divine'. But because divinity and humanity are distinct, we must reject this proposition. Now there is a way to take the proposition so that it is true, namely, if we were to add the demonstrative 'this' to 'human being' and get 'Christ as this human being is God'. The demonstrative creates the thought that 'this man', or the person Jesus Christ, and not human nature, is God. ${ }^{44}$ And that proposition is true, since the Word and Jesus are the same person. But it is more natural to take the reduplication to refer to the nature, and so as false.

However, one might object that 'Christ as a human being is God' is true because Christ as a human being does things only God can do. ${ }^{45}$ Consider his saving mysteries: all of them bear saving power for us. Christ as a human being forgave the sins of the paralytic! Christ, as a human being, does divine things (i.e. 'is God'). Yet Aquinas thinks that this reduplicative proposition fails to describe Christ's saving mysteries. For persons, signified by concrete terms, do actions. Natures do not act. In Christ's mysteries as scripture tells about them, $h e$ is the actor. Christ's two natures and energies are principles of action, but they belong to him as to a single subject who alone does the actions narrated in the Gospels. ${ }^{46}$

To draw attention to the thought that Christ is one person, Aquinas adopts adverbial modifiers to speak of him as the subject of these mysteries. For adverbs focus our

\footnotetext{
${ }^{41}$ Thanks to Mitchell Kennard for helpful conversation about these texts.

${ }^{42}$ Aquinas, ST 3.16.10; cf. 3.16.5.

${ }^{43}$ Aquinas, ST 3.16.11.

${ }^{44}$ Aquinas, $S T$ 3.16.11.3.

${ }^{45}$ Aquinas, ST 3.16.11.2.

${ }^{46}$ On hypostatic union, see Aquinas, ST 3.2.1-2, and on Christ's two energies or operations, cf. 3.19.1.
} 
thoughts on modes of action, which belong to actors. Thus, Aquinas replaces 'Christ as a human being is God' with linguistic tools more focused on the thought that Christ is a single subject.

'The son of God has on earth the power of forgiving sins', not in virtue of human nature, but the divine nature, in which divine nature the power of forgiving sins is established authoritatively (per auctoritatem); yet in human nature it is established instrumentally and ministerially (instrumentaliter et per ministerium). ${ }^{47}$

Here he adopts two adverbial modifiers that correspond with Christ's two natures: what the Logos does as God authoritatively he does by his humanity instrumentally forgives the sins of the paralytic. These adverbs focus our attention not on two natures as separate subjects of action, but on two different modes of action that belong to the same subject. He forgives sins in two modes: as God authoritatively, and as a human being instrumentally.

Aquinas' approach focuses us on the subject of the forgiveness of sins, the eternal Son of God, who undertakes these actions in modes that go with the two natures he has. As I have been emphasising, persons are the subjects of actions, but they act in certain modes according to the natures they have. So Christ forgives sins, but in two ways: as God authoritatively, and as a human being instrumentally. Now 'instrument' here does not have the sense of blunt or inactive instrumentality, but 'living' and 'rational' instrumentality. Christ's humanity, the instrument of his divinity, is a rational and volitive instrument, or in his lexicon, an 'animate instrument'. ${ }^{48}$ This notion arises from Aquinas' biblical intuition that Christ's humanity is the particular means whereby God directly and immediately brings our salvation about. For all of Christ's human actions and sufferings were 'operated instrumentally' in relation to his divinity. ${ }^{49}$ This means that all of Christ's actions he undertook as a human being have saving power. These actions are primarily his saving mysteries, but could be interpreted to extend to his whole life. And all of this is intended to retain the ontological language of two natures but discipline it to the biblical thought that Christ is one person. ${ }^{50}$

As the paralytic laid before his feet, God the Word forgave his sins. He did this in two ways: as God authoritatively and as a human being instrumentally. Though both of his natures retained their proper energies, each doing what is proper to it, he forgave the man's sins. God himself in the flesh did this; that we can utter such a sentence remains astoundingly difficult to grasp but beautiful in its glory.

\footnotetext{
${ }^{47}$ Aquinas, ST 3.16.11.2.

${ }^{48}$ Aquinas, III Sent, d. 13, a. 1, ad 4. Cf. Aquinas' discussion of Christ's two wills in ST 3.18.1, 4.

${ }^{49}$ Aquinas, ST 3.48.6. I treat this claim more broadly in my 'The Flesh of the Logos, Instrumentum divinitatis: Retrieving an Ancient Christological Doctrine', International Journal of Systematic Theology, forthcoming. The standard historical and theological study of this doctrine can be found in Theophil Tschipke, L'humanité du Christ comme instrument de salut de la divinité, trans. Philibert Secretan (Fribourg, 2003).

${ }^{50} \mathrm{My}$ thanks to Will Bankston and Fred Sanders for their comments on a previous draft of this paper.
}

Cite this article: Moser JD (2020). Tools for interpreting Christ's saving mysteries in scripture: Aquinas on reduplicative propositions in christology. Scottish Journal of Theology 73, 285-294. https://doi.org/10.1017/ S0036930620000617 